 \\ UF | FLORIDA

\author{
UFm
}

\section{Horizon 321 - A new winter oat cultivar for both grain and forage 1}

Ann Blount, Ronald Barnett, Jerry Johnson, Cheryl Mackowiak, and Yoana Newman²

Horizon 321 is a new winter oat cultivar that was co-developed by University of Florida (UF) and University of Georgia (UGA). Horizon 321 is a mid-season winter oat with exceptional grain and forage production, good test weight and excellent disease resistance. This cultivar originated from a cross between a Coker breeding line (Ck92Ab719) and Horizon 314. Horizon 321 is a novel and distinct variety that is most similar in appearance to Horizon 314 , however it typically heads three days earlier and has a higher test weight than Horizon 314. Horizon 321 is an excellent grain and forage oat adapted to the southeastern U.S.

Horizon 321 has a winter growth habit, with a low vernalization requirement. Horizon 321 is relatively tall, with good winter survival, moderate straw strength and excellent crown rust resistance.

Horizon 321 is resistant to prevalent races of crown rust, is susceptible to prevalent races of stem rust, and is moderately susceptible to barley yellow dwarf virus. Delaying planting until cooler weather prevails tends to alleviate the spread of the virus since it is aphid vectored. When planted early fall for forage, Horizon 321 is considered to be very disease resistant although BYDV infection may result in some stunting and leaf discoloration.

\section{$\underline{\text { Grain Production }}$}

Horizon 321 ranked highest for grain yield among the 20 entries and had good test weight in the 2001 Elite Oat Trials. It has ranked in the top tier of adapted oat cultivars in state variety trials. In the 2002 USDA Uniform Oat Nursery (12 locations, 9 southern states), Horizon 321 ranked $1^{\text {st }}$ for grain yield, had above average test weight, low lodging, and was resistant to crown rust .

\section{$\underline{\text { Forage Production }}$}

Horizon 321 has been a reliable forage producer and has been recommended for grazing and hay production. This oat also fits well in dairy silage operations where high quality cool-season forages are utilized for greenchop or silage. Data from various state variety trials report excellent grain and forage yields for this oat, which makes it suitable for both grain and forage production. Three-year state-wide

1. This document is SS AGR 280 one of a series of the Agronomy Department, Florida Cooperative Extension Service, Institute of Food and Agricultural Sciences, University of Florida. Original publication date October 2007. Visit the EDIS Web Site at http://edis.ifas.ufl.edu.

2. Ann Blount, associate professor, Agronomy Department, North Florida Research and Education Center--Marianna, FL; Ronald Barnett, professor, Agronomy Department, North Florida Research and Eduction Center--Quincy, FL; Jerry Johnson, University of Georgia; Cheryl Mackowiak, assistant professor, North Florida REC - Quincy, FL; Yoana Newman, assistant professor, Agronomy Department; Florida Cooperative Extension Service, Institute of Food and Agricultural Sciences, University of Florida, Gainesville, FL 32611.

The Institute of Food and Agricultural Sciences (IFAS) is an Equal Opportunity Institution authorized to provide research, educational information and other services only to individuals and institutions that function with non-discrimination with respect to race, creed, color, religion, age, disability, sex, sexual orientation, marital status, national origin, political opinions or affiliations. U.S. Department of Agriculture, Cooperative Extension Service, University of Florida, IFAS, Florida A. \& M. University Cooperative Extension Program, and Boards of County Commissioners Cooperating. Larry Arrington, Dean 
seasonal forage yield for Horizon 321 was $8292 \mathrm{lb} / \mathrm{A}$

in Georgia, and in 2007 it yielded $5449 \mathrm{lb} / \mathrm{A}$ in north

Florida under dryland conditions.

Horizon 321 is sold as a class of certified seed

by variety name only. Horizon 321 was released

exclusively to Plantation Seeds, Inc., Newton, GA.

Horizon 321 oat is considered to be an excellent choice for grain and forage use across the southeastern U.S. 